teaching, and so both of us remembering the objects of our profession, we shall endeavour worthily to walk in the footsteps of those who have gone before us, and strive to sustain the reputation of a school of medicine, which for half a century has been noted for much good work, done by both those who taught and those who studied therein.

\section{ABSTRACT OF A}

\section{apeture}

INTRODUCTORY TO THE COURSE ON

\section{P R A C T I C A L S U R G E R Y.}

By S. MESSENGRR BRADLFY, F.R.C.S.,

SURGBON TO THE MANCHFSTER ROYAL INFIRMARY, AND JACTURBR ON PRACTICAL SURGEHY AT OWHNS COLLEgh.

The lecturer commenced by defining the meaning and ocope of Practical Surgery, which he identified with the art of surgery as distinguished from the science, and proceeded by saying that the art made extraordinary progress more than two thousand years ayo, but failed to advance further from lack of the companionsbip of science; whiob, bowever, though late, at length appeared, and now they were freely and fearlessly advancing along the difficult path of progress. In sketching the rise and progress of the art, the lecturer said that, doubtless, rude attempts at surgery must have been almost coeval with the evolution of man, but that we had no distinct surgical records for ages after the civilisation of many great nations. There were cycles, he observed, in the mental history of the world-at certain distant periods a nation suddenly bursting into the full flower of genius, and this, not in one, but in almost every branch of buman knowledge. Hippocrates lived at such a time-the golden age of Grecian history. The lecturer sketched his career and dwelt upon his wurk, especially bis treatise on Fractures and Dislocations, which he considered equal in many respects to anything that had since appeared.

Surgery thus founded under the inspiratinn of the Socratic philosophy, and inspired by the genius of Hippocrates, continued to advance, observed the lecturer, hy the double path of observation and of reason. From Greece the art was carried to Rome, and in tracing its history we were next arrested by the names of Celsus, A.D 50, and of Galen, A.D. 130, both of whom resided in the Imperial city. At this epoch came a balt; the people turned from the study of political liberty to a blind following of authority. An intellectual daikness slowly descended upon the nations, which was not removed until $B_{u} c o n$, with his inductive philosophy, revived the Hippocratic reasnning. So great, however, was the impulse given to learning by the Father of Medicine, that a balting progress continued to be made for some time after Galun's death. In the meantime a knowledge of the art of surgery had been conveyed to the Arabs, who had eaptured Al+xandria, which was then the chief seat of learning, and the followers of the art had divided into three groups-the E "pirics, the Rationalists, and the Methodists. Of these the Rutionalists were incomparably the most enlightened, and to them belonged the Arab writers Rhazes, Albncasis, and others, along with the learned Greek, Paulus Egiveta. In bis hands, indeed, ancient surgery reached its climacteric, and the lecturer selected bis treatment of varic so veins as an illustration of his mental grasp and surgicul thoroughness.

With Egineta, Mr. Bradley went on to say, the progress ended; the art still continued to be practised by the Arabs, but nothing worthy of not nccurred until the eleventh century, when one Constantius curried a knowledge of the art from Egypt to Salermo in Iraly, which for some time continued to be its principal home.

Surgery did not, bowever, much benefit from the change of residence, but another arid more fruitful soil was about to receive the seed; for in 1295, Lanfrunc, travelling from Milan to Paris, for the first time established a school of surgery in France. In England, the bistory of the art was perhaps more chequered thun in Frunce. Until 1320, when John of Gaddesden left Oxford, there was no Enulish school of surgery, and in spite of the fios intercourse between France and England, Euglish surgery continued to be but a poor and barbarous art for some time to come. It languished in the bauds of the priests, and suffered still more from falling into the hands of ighorant laymen; nor was it, indeed, until the seventeenth century that a school of surgery worthy of England was estublished by Richard Wiseman. Surgery here, as in France, suffered long and severely from being considered an inferior and humbler urt than medicine. It was long in being emancipated from this thraldom. The phyaician was socially, intellectually, and educationally the superior of the su 'geon, and he lorded it over his humbler brothers with a high hand. With Wiseman, however, this state of things came to an end; the art of surgery was at length placed upon a scientific basis, and in the long roll of names between that day and this we bad nothing to blush for in English surgery, confided as it bad heen to the hands of such men as Cheselden, Hunter, White, Putt, Conper, and by them wortbily handed down to Brodie and to Paget. The lecturer, by way of illustrating the slow progress of the surgical art, detailed the history of the suryical treatment of aneurism and vesical calculus, and then passed to consider the condition of the art at the present day. He tbus concluded:-

"And now, gentlemen, what is to be said of the art of surgery at the present day? We live in an age of greatdiscoveries, of widespread mental activity. Is our art holding its own, and advancing equally with others? It may be-nay, I think it is-too much to claim such houour for our art, but this must be conreded that at no period since. the ripe Grecian summer of long ago bas so much been accomplished as in this our day. Barely catalogued, tho recent triumphs of surgery are numerous and splendid. Ophthalmic surgery has been raised from the bumblest position to the state of an almost perfect art. Laryngeal surgery in its entirety is the gift of the present age. So. much has been done in obstetric work as almost, to constitute it a fresh branch of our art, while this is altogether the case with ovarian operations, by which hundreds of valu. able lives are yearly snatched from a lingering and painful death. In reparative surgery the process introdaced by Rtverdin gives us a control over large wounds previously undreamt of; while the plan of Esmarch, enubling us to take our pound of flesh without shedding one drop of Christian blood, gives us a greatly extended power in operations upon the bones or joints, or in operations upon the extremities, involving a deep and tedious dissection. Many deformities are $n \cap w$ hopefully treated which, a sbort time since, were deemed beyund the surgeon's art, while most operations are so much simplifed that the resulting. success is materially increased. But, important as are each and all of these, they are but details when compared with the recent addition to our art of three great principles-the principles of anæstbesia, antisepticity, and electricity. ..... All these discoveries, and many more besides, are due to the late but happy union of science with art. Until science had created a knowledge of pathology and physiology, the art of surgery was bound band and foot; but the fetters were removed, and progress bad been immediate and con tinuous. Srill much remains to do. Of the nature of that process which lies at the root of almost every disease and almost all repair - inflammation-we are nearly as completely in the dark as ever; while over the destroying influence of malignant growthe and animal poisons we possess no more controlling power than Hippoerates. Room bere for the patient and intrepid explorer, who may yet advance with bope and even confidence; for, though there is much that is gloomy before and around bim, yet, of a trutb, 'the people who walked in darkness have seen a great light'the light of science-a light not uncertain or fitful, but steady and ever brightening; so that, asking, 'Watchman, will the night soon pass?' he may with a hopeful heart: await the answer: "The night is far spent; the day is at band." "

IT is announced that the Secretary of State for War has approved the appointment of Surgeon-Mujor F.S. B. De. Chaumont, M.D., as Professor of Military Hygiene at the Army Medical School, Netley. 